\title{
Al-chizan
}

ISSN 1907-0985, E ISSN 2442-8256

Vol. 17, No. 1, 2021, h. 27-42

DOI: https://doi.org/10.30603/am.v17i1.2061

\section{Maqāshid Syari'’ah Jasser Auda: Sebuah Sistem Pendekatan Dalam Hukum Islam Kontemporer}

\author{
Syarifuddin \\ Institut Agama Islam Negeri (IAIN) Palangkaraya \\ Email: syarifuddin@iain-palangkaraya.ac.id
}

\begin{abstract}
Abstrak: Maqāshid merupakan tujuan yang ingin dicapai melalui penerapan agama dengan basis memaksimalkan maslahah dan meminimalisir mafsadah. Originalitas pemikiran maqāshid Auda terletak pada pergeseran paradigma dan pengembangan maqāshid melalui sebuah sistem pendekatan yang dilakukannya. Ini dikembangkan Auda dengan melihat teori maqāshid klasik yang cenderung individual, kaku, sempit, bahkan terkesan hierarkis. Auda menggeser maqāshid klasik yang coraknya perlindungan dan penjagaan menjadi pembangunan dan hak-hak manusia. Di samping itu, Auda juga mendekati maqāshid dengan fitur-fitur sistem yang Auda buat, antara lain: pengartian, keutuhan, keterbukaan, hirarki yang saling terkait, situasi/keadaan, dan tujuan. Eksistensi sebuah fitur terletak pada kebermaksudannya (al-maqāshidiyah).
\end{abstract}

Kata Kunci: Maqāshid Syarī'ah, Jasser Auda, Sistem Pendekatan, Hukum Islam

\section{Maqāshid Syarī'ah Jasser Auda: a System Approach in Contemporary Islamic Law}

\begin{abstract}
Maquashid is a goal to be achieved through the application of religion on the basis of maximizing maslahah and minimizing mafsadah. The originality of maqasid Auda's thoughts lies in the shifting-paradigm and the development of maqāsid through a system approach that he takes. This was developed by Auda, because he saw the classical maqashid theory which tended to be individual, rigid, narrow, and even seemed hierarchical. Auda shifted the classical maqāshid whose styles were protection and preservation (guarding) into development and human rights. In addition, Auda also approached the maqashid with the features of the system he created: cognition, wholeness, openness, interrelated hierarchy, multidimensional situation, and porposefulness (goal). The existence of a feature lies in its purpose.
\end{abstract}

Keywords: Maqāshid Syarì'ah, Jasser Auda, Systems Approach, Islamic Law 


\section{A. Pendahuluan}

Ajaran Islam yang universal dan komprehensif tentunya membawa pada adanya berbagai paradigma dalam memahami ajaran-ajaran Islam yang bersumber dari Alquran dan hadis Rasulullah saw, khususnya dalam kajian hukum Islam. Hukum Islam hadir di tengah masyarakat memiliki tujuan yang hendak dicapai, dan dalam hal ini dikenal dengan istilah maqāshid al-syarī'ah. Pembahasan maqāshid al-syari'ah ini tidak luput dari perhatian para ulama dan pakar hukum Islam, di mana sebagian ulama menempatkannya pada bagian pembahasan ushul fiqh, dan sebagian lagi menempatkannya pada kajian filsafat hukum Islam. ${ }^{1}$

Salah satu ulama intelektual-muslim modern yang fokus terhadap pengkajian maqāshid adalah Jasser Auda. Dalam bahasa Auda, ada dua faktor yang melatarbelakangi pemikiran maqāshid-nya, yaitu adanya krisis kemanusiaan (ajmah insaniyah) dan minimnya metode (qushur manhazhiy) untuk menyelesaikannya. ${ }^{2}$ Krisis kemanusiaan sebagai faktor pertama merupakan realitas yang dialami oleh hampir semua negara-negara muslim, di mana angka kemiskinan, pengangguran, minimnya tingkat pendidikan, keamanan, pemerataan ekonomi serta kesejahteraan sosial belum terwujud. Bahkan laporan terakhir Human Development Index (HDI) menunjukkan tidak ada satupun negara muslim yang masuk sepuluh peringkat pertama. Belum lagi adanya aksi-aksi teror, yang mengatasnamakan hukum Islam (in the name of Islamic law) membuat semua orang khawatir, takut, dan was-was. Realiatas ini kemudian membuat Jasser menanyakan apakah ini yang disebut dengan hukum Islam.

Berangkat dari realitas ini, kemudian Jasser Auda melihat ada sesuatu yang bisa ditawarkan kepada dunia, yang dalam hukum Islam sebenarnya jarang disentuh dan dikembangkan, yaitu konsep maqāshid syari'ah. Akan tetapi, ia juga harus realistis, bahwa menawarkan konsep maqasid apa adanya merupakan upaya sia-sia. Hal ini, tidak lepas dari corak maqasid lama yang kaku, sempit, dan

\footnotetext{
${ }^{1}$ Ghofar Shidiq, “Teori Maqashid al-Syari'ah," Sultan Agung, Vol. XLIV No. 118 JuniAgustus 2009; 118.

2Jaser Auda, "Khatutun 'Ammah li Naqlah Manhajiyah fi Kasyfi wa Taf'il Maqasid alQur'an al-'Azhim,” Makalah, dalam http://www.jasserauda.net, diakses pada tanggal 17 September 2020.
} 
heararkis, pada tataran tertentu justru tidak memberikan efek positif terhadap perkembangan Islam umumnya, dan hukum Islam khususnya. Berangkat dari situ, Jasser Auda menggunakan maqasid syariah sebagai basis pangkal tolak filosofi berpikirnya dengan penggunakan pendekatan sistem sebagai metode berpikir dan pisau bedah analisisnya. Tidak berhenti di situ, Auda juga menawarkan konsep maslahah yang lebih terukur melalui Human Development Index (HDI) dan Human Development Targets (HDT).

Selain memperbaharui teori maqasid lama, Jasser Auda juga menyajikancfakta sejarah, bahwa hukum Islam adalah lahir dari Alquran dan hadis. Penafsiran dan ijtihad terhadap kedua sumber tersebut melahirkan dinamika kecenderungan, yaitu: era tradisionalis, modern, dan post-modern. Di era postmodern ini dalam memecahkan permasalahan yang dihadapi oleh umat manusia perlu proses dialogis. Proses dialogis yang dimaksud adalah adanya tegur sapa antara bangunan dasar cara berpikir umat manusia (humanities) di satu sisi dan bangunan dasar cara berpikir keagamaan Islam (ulum al-din) di sisi yang lain. Dengan adanya proses dialogis di atas, maka mau tidak mau, setiap orang harus bersentuhan dengan metode filsafat (rasional) dan metode sains (empiris) sekaligus. Dengan kata lain, memperkenalkan dan mendiskusikan hukum Islam, tidaklah cukup hanya berkutat pada sekitar syari'ah, ushul fiqh, dan fiqh. Akan tetapi, harus juga dengan pendekatan lain yang sifatnya interdisipliner. Di sinilah kemudian Auda menawarkan metode baru apa yang ia sebut dengan "a system approach"dalam mendekati maqasid syariah sebagai filsafat hukum Islam.

Para ahli teori hukum menjadikan maqashid al-syari'ah sebagai sesuatu yang harus dipahami oleh mujtahid yang melakukan ijtihad. Adapun inti dari teori maqāshid syari'ah adalah untuk mewujudkan kebaikan sekaligus menghindarkan keburukan, atau menarik manfaat dan menolak madharat. Istilah yang sepadan dengan inti dari maqāshid syari'ah tersebut adalah maslahat, karena penetapan hukum dalam Islam harus bermuara kepada kemaslahatan.

Allah swt. sebagai syari'yang menetapkan syariat tidak menciptakan hukum dan aturan begitu saja. Akan tetapi hukum dan aturan itu diciptakan dengan tujuan 
dan maksud tertentu. Ibnu Qayyim al-Jauziyah sebagaimana dikutip oleh Umam menyatakan bahwa tujuan syari'at adalah kemaslahatan hamba di dunia dan di akhirat. Syariat semuanya adil, semuanya berisi rahmat, dan semuanya mengandung hikmah. Setiap masalah yang menyimpang dari keadilan, rahmat, maslahat, dan hikmah pasti bukan ketentuan syariat. ${ }^{3}$

Sementara itu, perubahan-perubahan sosial yang dihadapi umat Islam di era modern telah menimbulkan sejumlah masalah serius berkaitan dengan hukum Islam. Di lain pihak, metode yang dikembangkan para pembaru dalam menjawab permasalahan tersebut terlihat belum memuaskan. Dalam penelitian mengenai pembaruan hukum di dunia Islam disimpulkan bahwa metode yang umumnya dikembangkan oleh pembaru Islam dalam menangani isu-isu hukum masih bertumpu pada pendekatan yang terpilah-pilah dengan mengeksploitasi prinsip takhayyur dan talfiq. ${ }^{4}$ Oleh karena itu menjadi kebutuhan yang sangat urgen agar para pembaru Islam saat ini merumuskan suatu metodologi sistematis yang mempunyai akar Islam yang kokoh jika ingin menghasilkan hukum yang komprehensif dan berkembang secara konsisten. ${ }^{5}$

Dengan latar belakang tersebut pengkajain terhadap konsep maqasid syariah sebagai a system approach yang dicanangkan oleh Jasser Auda perlu diketahui dimana maqasid syariah sebagai tujuan hukum Islam dan sebagai sebuah teori sistem (system theory) yang perlu ada pengembangan selanjutnya.

\section{B. Biografi Jasser Auda (1966- Sekarang)}

\section{Setting Sosio-Historis}

Jasser Auda dilahirkan pada tahun 1966 di Kairo, Mesir. Sebagai seorang yang dilahirkan pada keluarga yang taat beragama, sejak kecil dia sudah terbiasa dengan ilmu-ilmu keislaman tradisional. Ditambah lagi, dia hidup di sebuah negeri

${ }^{3}$ Khairul Umam, Ushul Fiqih (Bandung, Pustaka Setia, 2001), 127.

${ }^{4}$ J. N. D. Anderson, Law Reform in the Muslim World (London: University of London Press, 1976), 42. 1982), 101.

\footnotetext{
${ }^{5}$ John L. Esposito, Women in Muslim Family Law (Syracuse: Syracuse University Press,
} 
yang dalam sejarah peradaban Islam dikenal sebagai negara yang iklim akademik, sumber pengetahuan keagamaan tidak diragukan lagi. Dia merupakan keponakan dari Abdul Qadir Auda, tokoh Ikwanul Muslimin (IM), pengarang kitab alTasyri'al-Jinai al- Islami, yang bagi sebagian kalangan menjadi sumber rujukan ketika berbicara tentang hukum pidana Islam. Jasser Auda adalah intelektual muslim yang dalam dirinya bersentuhan dengan dua tradisi sekaligus: barat dan timur; tradisional dan modern.

Sejak muda, Auda sudah terbiasa mengaji secara tradisional di Masjid AlAzhar, yang memungkinkannya bisa mengakses pemikiran-pemikiran turast (kitab) klasik. Di samping belajar secara tradisional di masid Al-Azhar, ia sekaligus kuliah di jurusan ilmu komunikasi, Cairo University, Mesir, pada tingkat strata satu dan dua.

\section{Karir Intelektual}

Jasser Auda dalam memperkayaan corak pemikirannya, tidak hanya berpuas diri hanya mendapat pengetahuan dari Mesir saja, akan tetapi, dia juga mendapat gelar B.A dari Jurusan Islamic Studies pada Islamic American University, USA, tahun 2001, dan Master Fikih diperoleh dari Universitas Islam Amerika, Michigan, pada fokus kajian maqāshid syarī'ah tahun 2004. Auda memperoleh gelar Ph.D dari Universitas Waterloo, Kanada, dalam kajian Analisis Sistem tahun 2006, dan gelar Ph.D yang kedua diperoleh dari University of Wales, Inggris, pada konsentrasi Filsafat Hukum Islam tahun 2008.

Beberapa jabatan penting pernah ini dudukinya, di antaranya Associate Professor di Fakultas Studi Islam Qatar (QFTS) dengan fokus kajian Kebijakan Publik dalam Program Studi Islam. Dia adalah anggota pendiri Persatuan Ulama Muslim Internasional, yang berbasis di Dublin; anggota Dewan Akademik Institut Internasional Pemikiran Islam di London, Inggris; anggota Institut Internasional Advanced Sistem Research (IIAS), Kanada; anggota pengawas Global Pusat Studi Peradaban (GCSC), Inggris; anggota Dewan Eksekutif Asosiasi Ilmuan Muslim Sosial (AMSS), Inggris; anggota Forum 
Perlawanan Islamofobia dan Racism (FAIR), Inggris dan konsultan untuk Islamonline.net. ${ }^{6}$

Sekarang Jasser Auda adalah direktur sekaligus pendiri Maqashid Research Center di Filsafat Hukum Islam di London, Inggris, dan menjadi dosen tamu untuk Fakultas Hukum Universitas Alexandria, Mesir, Islamic Institute of Toronto, Kanada dan Akademi Fikih Islam, India. Auda menjadi dosen mata kuliah hukum Islam, filsafat, dan materi yang terkait dengan isu-isu minoritas Muslim dan kebijakan di beberapa negara di seluruh dunia. Dia adalah seorang kontributor untuk laporan kebijakan yang berkaitan dengan minoritas Muslim dan pendidikan Islam kepada Kementerian Masyarakat dan Dewan Pendanaan Pendidikan Tinggi Inggris. ${ }^{7}$

Sampai sekarang Auda sudah menulis 25 buku dalam bahasa Inggris dan Arab, dan beberapa diantaranya sudah diterjemahkan ke dalam 25 bahasa lain. Selain itu, ratusan tulisan dalam bentuk jurnal, tulisan media, kontribusi tulisan di buku, ceramah umum, dan jurnal online yang tersebar di seluruh dunia, sebagai berikut:

- Maqasid al-Syariah, A Beginner Guide, London: The International Institute of Islamic Thought, 2007;

- Maqasid al-Shariah as Philosophy of Islamic Law: A System Approach, London: The International Institute of Islamic Thought, 2007;

- Fiqh al-Maqasid: Inathah al-Ahkam al-Syar'iyyah bi Maqashidiha, AlMa'had al-'Ali li al-Fikr al-Islamiyah;

- Rethingking Islamic Law for Minorities: Towards A Westren-Muslim Identity, London: The International Institute of Islamic Thought;

- Reclaiming The Mosque, London: The International Institute of Islamic Thought;

- Shari'a and Politics, London: The International Institute of Islamic Thought;

\footnotetext{
${ }^{6}$ Jasser Auda, Al-Maqasid Untuk Pemula, terj. 'Ali ‘Abdelmon'im (Yogyakarta: SUKAPress, 2013), 137-139. Lihat juga website: www.jasserauda.net, diakses pada 17 September 2020.

${ }^{7}$ Ibid.
} 
- Al-Mar'ah wa al-Masjid, London: The International Institute of Islamic Thought;

- Khatutun 'Ammah li Naqlah Manhajiyah fi Kasyfi wa Taf'il Maqasid alQur'an al-'Azhim, Makalah. ${ }^{8}$

Melihat latar belakang beliau seperti di atas, ada yang menarik dari Auda untuk diperhatikan, yaitu: Pertama, dia hidup di tengah-tengah era kontemporer, di tengah-tengah arus deras era global sekarang ini. Kedua, dia datang dari belahan dunia Eropa, namun mempunyai basis pendidikan Islam tradisional dari negara yang berpenduduk Muslim. Ketiga, Jasser Auda adalah salah satu intelektual minoritas Muslim yang hidup di dunia Barat, di wilayah mayoritas non-Muslim. Keempat, Jasser Auda mempunyai kemampuan untuk mendialogkan dan mempertautkan antara paradigma Ulüm al-Din, al-Fikr al-Islamī dan Dirasat Islamiyyah kontemporer dengan baik dengan Dirasat Islamiyyah yang menggunakan sains modern, social sciences dan humanities kontemporer sebagai pisau analisisnya dan cara berpikir keagamaannya. ${ }^{9}$

\section{Melacak Posisi Pemikiran Hukum Islam Jasser Auda}

Untuk melihat pemikiran maqāshid syari' 'ah Jaser Auda, terlebih dahulu dilihat di mana posisinya dalam peta pemikiran Islam. Hal ini terkait dengan a system approach yang ditawarkanya. Menurut Amin Abdullah, a system approach menghendaki perlunya mengusai dua approaches sekaligus secara profesional. Pertama, approaches yang terkait dengan dimensi waktu dan kesejarahan. Kedua, approaches yang berhubungan dengan konsep dan pemikiran kefilsafatan. ${ }^{10}$

\footnotetext{
${ }^{8}$ Untuk melihat semua karya Jasser Auda, lihat website: www.jasserauda.net.

${ }^{9}$ M. Amin Abdullah, "Epistemologi Keilmuan Kalam dan Fikih dalam Merespon Perubahan di Era Negara-Bangsa dan Globalisasi (Pemikiran Filsafat Keilmuan Agama Islam Jasser Auda)", Media Syariah, Vol. XIV No. 2 Juli-Desember 2012; 126.

${ }^{10}$ M. Amin Abdullah, "Hak Kebebasan Beragama dan Berkeyakinan: Pendekatan Filsafat Sistem dalam Usul Fikih Sosial,” Jurnal Salam, Vol. 14 No. 1 Januari-Juni 2011; 12.
} 
Auda mengajukan tiga lapis kunci masuk untuk melihat dan mengalisis dalam upaya mengembangkan ijtihad kontemporer, yaitu: tradisionalisme, modernisme, dan post-modernisme Islam.

1. Tradisionalisme Islam (Islamic traditionalism). Ada empat varian, yaitu: (a) Tradisonalisme bermazhab (scholastic traditionalism), dengan ciri berpegang teguh pada salah satu mazhab fikih klasik sebagai sumber hukum dan jarang menggunakan dalil yang mandiri. Mereka membolehkan ketika sudah tidak ada lagi ketentuan hukum pada mazhab yang dianut; (b) Neo-tradisionalisme bermazhab (scholastic neo-traditionalism), bersikap terbuka terhadap lebih dari satu mazhab untuk dijadikan referensi terkait suatu hukum yang sah, dan tidak terbatas pada satu mazhab saja. Ada beberapa jenis sikap terbuka yang diterapkan, mulai dari sikap terhadap seluruh mazhab fikih dalam Islam, hingga sikap terbuka pada mazhab Sunni atau Syiah saja; (c) Neoliteralisme (neo-literalism) adalah aliran yang menolak ide untuk memasukkan purpose atau maqasid sebagai sumber hukum yang sah (legitimate) dan (d) Teori-teori berbasis ideologi (ideology-oriented theories). Aliran ini merupakan aliran yang mengkritik rasionalitas modern dan nilainilai sentral Eropa yang dianggap biasdan penuh kontradiksi.

2. Modernisme Islam (Islamic modernism). Setidaknya ciri pokok aliran ini adalah adanya upaya mengintegrasikan pendidikan Islam dan Barat yang diperoleh oleh para tokohnya, untuk diramu menjadi tawaran baru bagi reformasi Islam dan penafsiran kembali. Aliran ini ada lima varian yang memiliki corak yang berbeda, yaitu: (a) Reinterpretasi reformis (reformist reinterpretation); (b) Reinterpretasi apologis (apologetic reinterpretation); (c) Teori-teori berbasis maslahah (maslahah- based theories); (d) Revisionis usul (usul revisionism); dan (e) Re-interpretasi berbasis sains (science-oriented reinterpretation).

3. Post-modernisme (post-modernism). Beragam definisi diberikan oleh ahli terkait itu apa posmodernisme. Bila dirangkum, posmodernisme merupakan kritik, koreksi, wajah arif, bahkan proyek modernisme yang belum selesai. 
Akan tetapi, ciri yang mencolok, bahwa posmodernisme adalah kekuatan atau proses intelektual, politik dan kultural yang kontemporer, yang bertujuan untuk mendekonstruksi dan memformat ulang banyak tradisi artistik, kultural, dan intelektual konvensional. Dengan demikian, metode yang paling umum digunakan dari posmorenisme adalah dekonstruksi. Deconstruction (dekonstruksi; pembongkaran) merupakan tawaran dari Derrida sebagai ganti dari destruction (penghancuran). Dekonstruksi berarti menata kembali dengan konsep dasar yang sama sekali baru. ${ }^{11}$

Berbicara ijtihad kontemporer tidak terlepas dari penggunaan pemikiran secara maksimal, dan hal ini dinyatakan Muhammad Iqbal bahwa ijtihad sebagai prinsip gerak dalam struktur Islam. Penggunaan pemikiran secara maksimal (ra'y) diarahkan untuk menggali, menemukan, memilih, memilah, menganalisis dan menetapkan suatu pemikiran hukum. Ruang gerak pemikiran ijtihad dalam literatur ushul fiqh pada umumnya dibatasi pada hukum-hukum syara' yang bersifat dzanniyat, tidak diperbolehkan pada hukum-hukum syara' yang bersifat qath'iyyat. $^{12}$

Ulama sepakat bahwa teks-teks Alquran dan sunnah Rasulullah saw. yang tidak diragukan lagi validitasnya (qath'iyat) datang dari Allah dan Rasul-Nya, bukan menjadi lapangan pemikiran ijtihad. Oleh karena itu, Zuhaili mengatakan sebagaimana dikutip Yafie bahwa kategori pemikiran hukum Islam yang sudah diketahui oleh umum, diberlakukan secara umum, sudah sedemikian jelas dan valid, aturan yang demikian disebut dengan al-ahkām al-ma'lümat min al-dìn bi aldharūrah wa al-badahah. ${ }^{13}$ Namun terlepas dari dalil-dalil dzanniyat, maka seorang

\footnotetext{
${ }^{11}$ Rizal Umanullah, "Review Book Membumikan Hukum Islam Melalui Maqasid Syariah", Makalah (Samarinda: Pascasarjana IAIN Samarinda, 2016), 45; dalam https://www.academia.edu/ 30866391/Riview_Book_Jaseer_Auda_MEMBUMIKAN_HUKUM_ISLAM_MELALUI_MAQASI D_SYARIAH, diakses tanggal 15 Januari 2021.

${ }^{12}$ Al-Amidi, al-Ihkām fî Ushūl al-Ahkām, Jilid 2, Juz 4 (Bairut: Dār al-Fikr, 1424 H/2003 M.), 212. Bandingkan Zakiyuddin Sya'ban, Ushūl al-Fiqh al-Islāmi (Mesir: Dār al-Ta'lif, 1965), 417. Lihat pula Wahbah al-Zuhaili, Ushūl al-Fiqh al-Islāmi, Juz 2 (Cet 2; Bairut: Dār al-Fikr al-Mu'ashir, 1998), 1080.

${ }^{13}$ Ali Yafie, "Posisi Ijtihad dalam Ketuhanan Ajaran Islam" dalam Ahmad Azhar Basyir, et.al., Ijtihâd dalam Sorotan (Bandung: Penerbit Mizan, 1988), 76.
} 
pemikir dapat pula melakukan ijtihad terhadap dalil-dalil qath'iyah. Hal ini dengan pemikiran bahwa secara metodologis jika seseorang ulama membuka pikiran dengan jernih dan prospektif kemudian mencermati gagasan dan pola pikir secara revolutif, dekonstruktif, reformulatif, dan rekonstruktif yang telah banyak ditawarkan oleh para cendikiawan Muslim abad modern ini, sekaligus dengan mengacu pada hasil-hasil pemikiran ijtihad kreatif dan inovatif Umar ibn Khattab pada masa dulu. Di sini terlihat adanya boleh berijtihad pada dalil-dalil hukum (teks-teks Alquran dan Sunnah) yang berifat qath'î. Kasus-kasus ijtihad Umar bila didekati dengan teori qath'i-dzanni, akan tergambar bahwa teks-teks yang ditinggalkan Umar adalah yang dzannî dilâlah, tetapi justru Umar melakukan pemikiran ijtihâd pada masalah-masalah yang sudah jelas dan tegas ditunjukkan oleh nash atau teks yang qath'i dilālah. ${ }^{14}$

Jika dianalisis secara dekonstruktif, teori qath' 'î-dzannī perlu dibongkar dari persepsi kemapanan yang selama ini banyak terdokumentasikan dalam umumnya literatur ushūl fiqh dan fikih. Salah satu contoh ijtihad Umar mengenai pendistribusian zakat, khalifah Umar tidak sepenuhnya mengaplikasikan petunjuk QS al-Taubah/9: 60, dan meninggalkan praktik distribusi yang dahulu dilakukan oleh Rasulullah saw. Umar tidak lagi memberikan bagian zakat kepada almuallafati qulübuhum (mereka yang hati dan kesetiaannya masih perlu perhatian dari kaum Muslimin) dengan argumentasi situasi dan kondisi sudah berubah. ${ }^{15}$

Mencermati hal tersebut dipahami bahwa corak pemikiran Auda adalah memberikan ruang terhadap pemikiran yang revolutif, dekonstruktif, reformulatif, dan rekonstruktif dalam membaca teks-teks dan dalil-dalil agama yang bersumber dari Alquran dan hadis Rasulullah saw., dalam artian terbukanya pintu ijtihad para ulama dalam mengeksplorasi persoalan-persoalan yang terjadi di masyarakat dengan melihat konsep kemaslahatan yang akan diperoleh oleh masyarakat tersebut.

\footnotetext{
${ }^{14}$ Maimun, "Reorientasi Ijtihad Kontemporer: Analisis Hukum Islam,” Al-Adalah, Vol. XI, No. 2 Juli 2013; 157-158.

${ }^{15}$ Ibid., 158.
} 


\section{Paradigma Pemikiran Jasser Auda terhadap Maqāshid Syarī'ah}

Maqāshid syarí'ah dalam kajian Islam sangat penting peranannya, ini terkait dengan posisinya sebagai tujuan dari syariah itu sendiri. Secara etimologi maqāshid adalah bentuk jamak dari maqshhad, yang mempunya arti, yaitu maksud (purpose), sasaran (abjective), prinsip (principle), niat (intent), tujuan (goal), dan tujuan akhir (end). Sementara secara terminologi maqāshid syarī'ah didefinisikan sebagai makna-makna yang dituju oleh syar'i untuk diwujudkan yang terdapat di balik ketentuan-ketentuan syariah dan hukum. Maqasid syariah sebagai sebuah teori, metodologi, dan terminus technicus, baru muncul pada abad VIII hijriah, di tangan Imam Syatibi, dengan kitabnya Al-Muwafaqat Sebelumnya, kajian maqasid masih satu paket dengan kajian al-maslahah al-mursalah. Setidaknya ada tiga alasan Syatibi disebut sebagai Bapak Maqāshid, yaitu Pertama, karena keberhasilan Syatibi menarik maqāshid yang semula hanya sekedar maslahahmaslahah lepas menjadi asas-asas hukum; Kedua, dari hikmah di balik aturan kepada dasar aturan; dan Ketiga, dari ketidaktentuan menuju keyakinan. ${ }^{16}$

Para ahli maqāshid klasik mengklasifikasikan maqasid sesuai dengan jenjang kemaslahatannya menjadi tiga tingkat: al-dharūriyyah (primer; keniscayaan), al-hājiyat (sekunder; kebutuhan), dan al-tahsiniyah (tersier; kemewahan). Kemudian, al-dharūriyah dibagi lagi kepada: hifz al-din (pelestarian agama), hifz al-nafs (pelestarian nyawa), hifz al-mal (pelestarian harta), hifz al- 'aql (pelestarian akal) dan hifz al-nasl (pelestarian keturunan). Sebagian ahli menambahkan hifz al-'ird (pelestarian kehormatan) untuk menggenapkan kelima al-maqāsid itu menjadi enam tujuan pokok/primer atau keniscayaan. Dari ketiga ketegori klasifikasi maqasid itu, hanya al-dharūriyah atau al-hājiyah yang bisa dijadikan bahan dan dasar untuk istinbat al-ahkām. Selain klasifikasi di atas, Abdul Majid an-Najjar membuat klasifikasi lain. Dilihat dari kekuatan sumber (quwwah al-subut) maqāshid dibagi atas: al-maqhasid al-qat'iyyah, al-maqhasid alzhanniyah, al-maqashid al- wahmiyah; dari keasliannya (bi hasab al-ashliyah)

\footnotetext{
${ }^{16}$ Nafsiyatul, "Konsep Maqasid Syariah dan Epistimologi Pemikiran Jasser Auda," Tesis (Yogyakarta: Pascasarjana Universitas Islam Negeri Sunan Kalijaga, 2016), 72.
} 
menjadi: maqāshid al-ushul dan maqāshid al-wasail. Akan tetapi, dengan perkembaangan zaman dan terjadinya globalisasi, mau tidak mau teori maqāshid tradisional itu harus dikembangkan. ${ }^{17}$

Menurut Auda, setidaknya ada beberapa kritikan yang disajikan oleh para ahli teoritikus maqāshid terhadap klasifikasi keniscayaan maqāshid tradisional, yaitu:

1. Teori maqāshid tradisional tidak memasukkan maksud khusus dari suatu atau sekelompok nash yang meliputi topik fikih tertentu;

2. Maqāshid tradisional masih berkutat di seputar individu, belum menyentuh ranah makro, seperi keluarga, masyarakat, dan umat manusia;

3. Maqāshid tradisonal tidak memasuk nilai-nilai fundamental, seperti keadilan (al-`adl) dan kebebasan (al-hurriyah);

4. Maqāshid tradisional masik dideduksi dari kajian literatur fikih, belum dari sumber-sumber syariat Alquran dan Sunnah. ${ }^{18}$

Upaya pengembangan maqāshid dari tradisionalisme menuju kontemporer inilah yang diupayakan oleh Auda dengan langkah-langkah sebagai berikut:

\section{Perbaikan pada Jangkauan Maqāshid}

Klasifikasi kontemporer membagi maqașid menjadi tiga tingkatan sebagai rangka perbaikan jangkauan hukum yang dicakup oleh maqāshid, yaitu: Pertama, maqasid umum (al-maqāshid al-'ammah), yaitu maqașid yang dapat diperhatikan pada hukum Islami secara keseluruhan, seperti keniscayaan dan kebutuhan yang dijelaskan di atas, dan nilai-nilai seperti keadilan (al-adl), universalitas (alkulliyah), kemudahan (al-taisir), dan kebebasan (al-hurriyah); Kedua, maqāshid khusus (al-maqāshid al-khassah), maqasid yang dapat diperhatikan pada salah satu bab tertentu dari hukum Islami, seperti kesejahteraan anak pada bab hukum keluarga, mencegah kejahatan pada bab hukum pidana, dan mencegah monopoli;

${ }^{17}$ Agus Afandi, "Maqasid al-Shariah sebagai Filsafat Hukum Islam sebuah Pendekatan Sistem versi Jasser Auda", Makalah, dalam https://cupdf.com/document/agus-afandi.html, diakses tanggal 17 September 2020; 71.

${ }^{18}$ Ibid., 72. 
Ketiga, maqāshid parsial (al-maqāshid al-juz`̃yyah), maqāshid ini adalah maksudmaksud di balik suatu teks atau hukum tertentu, seperti maksud terungkapnya kebenaran pada penetapan jumlah saksi tertentu pada kasus- kasus hukum tertentu. Maksud menghilangkan kesukaran dalam memperbolehkan orang sakit untuk tidak puasa, dan maksud menjamin makanan para fakir miskin dalam melarang kaum Muslimin untuk menyimpan daging pada hari-hari lebaran haji, dan lain sebagainya. $^{19}$

Dengan klasifikasi dan perluasan cakupan ini dapat digunakan untuk menyusun sebuah sistem hukum yang lebih utuh. Anggapan ini karena boleh jadi, yang selama ini ia dianggap sebagai maqāshid syarí'ah yang harus diwujudkan, akan tetapi dengan klasifikasi ini, ternyata ada maqāshid yang lebih fundamental yang harus diwujudkan lebih dahulu. Begitu juga, dengan klasifikasi ini bisa menghindarkan adanya kemungkinan kontradiksi dan pertentangan antara beberapa maqāshid, di mana maqāshid khusus tidak boleh bertentangan dengan maqāshid umum.

\section{Perbaikan pada Jangkauan Orang yang Diliputi}

Pengembangan selanjutnya adalah memperbaiki kekurangan teori maqasid klasik terkait coraknya hanya membahas jangkauan individual, maka para cendekiawan Muslim modern dan kontemporer memperluas jangkauan manusia yang lebih luas, yaitu: masyarakat, bangsa, bahkan umat manusia. Misalnya pandangan Ibn Asyur, memberikan prioritas pada maqāshid yang berkaitan dengan kepentingan bangsa atau umat di atas maqāshid seputar kepentingan individual; Rasyid Ridha memasukkan reformasi dan hak-hak wanita ke dalam teori maqāshid; dan Yusuf al Qaradhawi menempatkan martabat dan hak-hak manusia pada teori maqāshid-nya. Dengan adanya pengembangan dari para ilmuwan ini memberikan kesan bahwa maqāshid itu individual, kaku dan hierarkis bisa hilang dengan sendirinya.

\footnotetext{
${ }^{19}$ Abbas Arfan, "Maqasid al-Syari'ah sebagai Sumber Hukum Islam: Analisis terhadap Pemikiran Jasser Auda”, Al-Manāhij, Vol. 7, No. 2 (2013); 186-187.
} 
3. Perbaikan Sumber Induksi Maqāshid dan Tingkatan Keumuman Maqāshid

Para ahli maqāshid kontemporer memperkenalkan teori maqāshid umum baru yang secara langsung digali dari nash/teks Alquran dan hadis, bukan lagi dari literatur fikih dalam mazhab-mazhab fikih. Pendekatan ini secara signifikan memungkinkan maqāshid untuk melampaui historisitas keputusan fikih serta merepresentasikan nilai dan prinsip umum dari nash, maka hukum detail (ahkām tafsiliyat) dapat digali dari prinsip-prinsip menyeluruh (kulliyat).

4. Pergeseran Paradigma (Shiftting-Paradigm)

Selain memetakan perkembangan maqasid dari tradisional menuju kontemporer, Auda juga melakukan pergeseran paradigma (shifting-paradigm) dari teori maqāshid lama ke teori maqāshid baru terletak pada titik tekan keduanya. Titik tekan maqāshid lama lebih pada protection (perlindungan) dan preservation (penjagaan, pelestarian) sedangkan teori maqāshid baru lebih menekankan development (pembangunan, pengembangan) dan human right (hak-hak manusia). Berangkat dari pergeseran ini kemudian, maka cakupan dan sasaran maqāshid menjadi lebih luas.

Berdasarkan landasan berpikir tersebut, Auda berkeyakinan bahwa tujuan dari hukum Islam (maqāshid al-syarī'ah al-Islamiyyah) menjadi prinsip fundamental yang sangat pokok dan sekaligus menjadi metodologi. Dengan jangkauan maqāshid yang lebih luas, maka efektifitas dari sebuah sistem diukur berdasar pada terpenuhinya tujuan yang hendak dicapai. Efektifitas dari sistem hukum Islam juga diukur berdasarkan terpenuhinya tujuan-tujuan pokoknya.

Untuk merealisasikan itu, Auda menawarkan Human Development Index (HDI) dan Human Development Targets (HDT) sebagai tujuan pokok dari kemaslahatan yang ingin dicapai. Dengan memadukan maqāshid syariah dan a system approach terutama pada fitur porposefulness; al-maqasidiyah, maka bisa ditarik dipetakan pergeseran paradigma dari maqāshid tradisionalisme menuju maqāshid kontemporer yang digambarkan pada tabel berikut ini: 


\begin{tabular}{|c|c|c|}
\hline No & Teori Maqāshid Klasik & Teori Maqāshid Kontemporer \\
\hline 1 & $\begin{array}{l}\text { Menjaga agama } \\
\text { (hifz al- din) }\end{array}$ & $\begin{array}{l}\text { Menjaga, melindungi dan menghormati } \\
\text { kebebasan beragama atau berkepercayaan }\end{array}$ \\
\hline 2 & $\begin{array}{l}\text { Menjaga keturunan } \\
\text { (hifz al-nasl) }\end{array}$ & $\begin{array}{l}\text { Teori yang berorientasi kepada perlindungan } \\
\text { keluarga; kepedulian yang lebih }\end{array}$ \\
\hline 3 & $\begin{array}{l}\text { Menjaga akal } \\
\text { (hifz al- aql) }\end{array}$ & $\begin{array}{l}\text { Melipatgandakan pola pikir dan research } \\
\text { ilmiah; mengutamakan perjalanan untuk } \\
\text { mencari ilmu pengetahuan; menekan pola pikir } \\
\text { yang mendahulukan kriminalitas kerumunan } \\
\text { gerombolan; menghindari upaya-upaya untuk } \\
\text { meremehkan kerja otak }\end{array}$ \\
\hline 4 & $\begin{array}{l}\text { Menjaga kehormatan; menjaga jiwa } \\
\text { (hifz al-'irdh) }\end{array}$ & $\begin{array}{l}\text { Menjaga dan melindungi martabat } \\
\text { kemanusiaan; menjaga dan melindungi hak- } \\
\text { hak asasi manusia }\end{array}$ \\
\hline 5 & $\begin{array}{l}\text { Menjaga harta } \\
\text { (hifz al-māl) }\end{array}$ & $\begin{array}{l}\text { Mengutamakan kepedulian sosial; menaruh } \\
\text { perhatian pada pembangunan dan } \\
\text { pengembangan ekonomi; mendorong } \\
\text { kesejahteraan manusia; menghilangkan }\end{array}$ \\
\hline
\end{tabular}

\section{E. Kesimpulan}

Maqāshid sendiri merupakan tujuan yang ingin dicapai melalui penerapan agama dengan basis memaksimalkan maslahah dan meminimalisir mafsadah. Originalitas pemikiran maqāshid Auda terletak pada pergeseran paradigma (shifting-paradigm) dan pengembangan maqāshid melalui a system approach yang ia lakukan. Auda mengembangkan teori ini dikarenakan melihat teori maqāshid klasik yang cenderung individual, kaku, sempit, bahkan terkesan hierarkis. Auda menggeser maqāshid klasik yang coraknya protection (perlindungan) dan preservation (penjagaan) menjadi development (pembangunan) dan human right (hak-hak manusia). Di samping itu, Auda juga mendekati maqāshid dengan fiturfitur sistem yang ia buat, seperti: cognition (pengartian), wholeness (keutuhan), openness (keterbukaan), interrelated-hierarchy (hirarki yang saling terkait), multidimensionalituy (situasi/keadaan), dan porposefulness (tujuan). Eksistensi sebuah fitur terletak pada kebermaksudannya (purposefulness; al-maqasidiyah). 


\section{Daftar Pustaka}

Abdullah, M. Amin. "Epistemologi Keilmuan Kalam dan Fikih dalam Merespon Perubahan di Era Negara-Bangsa dan Globalisasi (Pemikiran Filsafat Keilmuan Agama Islam Jasser Auda)", Media Syariah, Vol. XIV No. 2 Juli Desember 2012.

"Hak Kebebasan Beragama dan Berkeyakinan: Pendekatan Filsafat Sistem dalam Usul Fikih Sosial”, Jurnal Salam, Vol. 14 No. 1 Januari-Juni 2011.

Afandi, Agus. "Maqasid al-Shariah sebagai Filsafat Hukum Islam sebuah Pendekatan Sistem versi Jasser Auda", Makalah, dalam https://cupdf.com/document/agus-afandi.html

Al-Amidi. Al-Ihkām fỉ Ushūl al-Ahkām, Jilid 2, Juz 4. Bairut: Dār al-Fikr, 1424 $\mathrm{H} / 2003 \mathrm{M}$.

Anderson, J. N. D. Law Reform in the Muslim World. London: University of London Press, 1976.

Arfan, Abbas. "Maqasid al-Syari'ah sebagai Sumber Hukum Islam: Analisis terhadap Pemikiran Jasser Auda", Al-Manāhij, Vol. 7, No. 2 (2013).

Auda, Jaser. "Khatutun 'Ammah li Naqlah Manhajiyah fi Kasyfi wa Taf'il Maqasid al- Qur'an al-'Azhim," Makalah, dalam http://www.jasserauda.net, diakses pada tanggal 17 September 2020.

Auda, Jasser. Al-Maqasid Untuk Pemula, terj. 'Ali 'Abdelmon'im. Yogyakarta: SUKA-Press, 2013.

Esposito, John L. Women in Muslim Family Law. Syracuse: Syracuse University Press, 1982.

Maimun. "Reorientasi Ijtihad Kontemporer: Analisis Hukum Islam," Al-Adalah, Vol. XI, No. 2 Juli 2013.

Nafsiyatul. "Konsep Maqasid Syariah dan Epistimologi Pemikiran Jasser Auda," Tesis. Yogyakarta: Pascasarjana Universitas Islam Negeri Sunan Kalijaga, 2016.

Shidiq, Ghofar. "Teori Maqashid al-Syari'ah," Sultan Agung, Vol. XLIV No. 118 Juni-Agustus 2009.

Sya'ban, Zakiyuddin. Ushūl al-Fiqh al-Islāmi. Mesir: Dār al-Ta'lif, 1965.

Umam, Khairul. Ushul Fiqih. Bandung, Pustaka Setia, 2001.

Umanullah, Rizal. "Review Book Membumikan Hukum Islam Melalui Maqasid Syariah", Makalah. Samarinda: Pascasarjana IAIN Samarinda, 2016dalam https://www.academia.edu/30866391/Riview_Book_Jaseer_Auda_MEMBU

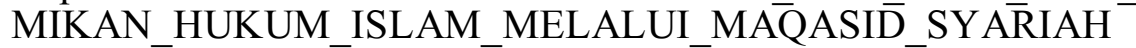

Yafie, Ali. "Posisi Ijtihad dalam Ketuhanan Ajaran Islam" dalam Ahmad Azhar Basyir, et.al., Ijtihâd dalam Sorotan. Bandung: Penerbit Mizan, 1988.

Al-Zuhaili, Wahbah. Ushūl al-Fiqh al-Islāmi, Juz 2. Cet 2; Bairut: Dār al-Fikr alMu'ashir, 1998. 